\title{
Combining Ability Studies on Brinjal for Yield and Yield Components Traits
}

\author{
R.I. Khobragade ${ }^{1 *}$, P.K. Nagre $^{2}$ and V.N. Nandeshwar ${ }^{3}$ \\ ${ }^{1}$ College of Agriculture Gadchiroli, (MS) \\ ${ }^{2}$ Faculty of Horticulture, Dr. Panjabrao Deshmukh Krishi Vidyapeeth, Akola (MS) \\ ${ }^{3}$ Dr. Panjabrao Deshmukh Krishi Vidyapeeth, Akola (MS), India \\ *Corresponding author
}

\section{Keywords}

Brinjal, Combining ability, gca, sca, Crosses, Parents, Yields

Article Info

Accepted:

12 July 2019

Available Online:

10 August 2019

\section{A B S T R A C T}

The present investigation entitled "Genetic analysis of $\mathrm{F}_{1}$ hybrids in brinjal (Solanum melongena L.)" was carried out at Main Garden, Department of Horticulture, Dr. Panjabrao Deshmukh Krishi Vidyapeeth, Akola. Eleven genotypes (Aruna, Bhandara local, Wadsa local, Bhatai local, Manjarigota, Chandur local, Ruchira, Krishna Kathi, White Round, DBSR-52, White Brinjal) were crossed in line $\mathrm{x}$ tester mating design during kharif 2013. All parents and resultant crosses with standard check Phule Arjun (F1) were evaluated during Kharif and summer season of 2014-15 in Randamised Block Design with three replications. Among female parents, Bhatai local, Wadsa local, Aruna and among male parents, DBSR-52, Ruchira, Chandur local were identified as good combiner for growth, flowering (earliness), higher yield and quality characters. Six crosses viz., Bhandara local x ManjariGota, Wadsa local x Chandur local, Wadsa local x White brinjal, Wadsa local x Ruchira, Aruna x Chandur local and Bhatai local x Ruchira exhibited significant sca effects for yield per plant and yield per hectare. The crosses viz., Wadsa local x Ruchira, Wadsa local x Chandur local, Bhatai local x Ruchira and Aruna x Chandur local were identified as promising hybrids on the basis of significant sca effects and both the parents involved in these crosses had good combining ability effects for yield per plant and most of the characters studied. Additive gene action was found to be predominant for all the characters in pooled mean, except plant spread where non-additive gene action was predominant. Analysis of genetic components of variation revealed that the importance of additive gene action operating in inheritance of yield and its important components.

\section{Introduction}

Brinjal (Solanum melongena L.), one of the most important vegetable crops, belongs to family Solanaceae. In India, it is known by baigan (HindI), Vangi (Marathi), Badanekai (Kannada), Katharikai (Tamil), Vankai (Telagu) etc. Internationally, it is referred as 
Egg plant (England) or Aubergine (France). India is regarded as the primary centre of origin/diversity of brinjal (Bhaduri, 1951 and Vavilov, 1931) and shows secondary diversity in South East Asia. The chromosome number of many species of solanaceae under non tuberous group is fairly stable as $2 \mathrm{x}=2 \mathrm{n}=$ 24. There are 38 Asian species, which includes 22 Indian species. There is a group of 5 related ones, namely $S$. melongena L., $S$. incum L., S. xanthocarpum, S. indicum L. and S. maccani(Choudhury, 1976). There are three main botanical varieties under the species melongen. The common brinjal type which is large, round or egg-shaped fruited forms belongs to group under var. esculentum. The long, slender types are included under var. serpentinum and the dwarf brinjal plants are put under var. depressum. India is the second largest producer of brinjal in the world only after China followed by Iran, Egypt, Indonesia, Japan, Spain, Italy, Bangladesh \& Pakistan where it is being grown extensively. Brinjal is cultivated in India, over an area of 0.67 million ha, sharing $6.5 \%$ to the total vegetable area, with an average annual production of 12.40 million tones, sharing $7.08 \%$ production with $18.53 \mathrm{MT} / \mathrm{ha}$ productivity compared to $26.5 \mathrm{MT} / \mathrm{ha}$ of world (Anon, 2017). In Maharashtra, it is grown on an area of 0.22 lakh ha with annual production of 4.33 lakh tonnes having productivity $19.78 \mathrm{MT} / \mathrm{ha}$. Nagpur, Satara, Solapur, Parbhani, Pune Sangali, Bhandara, Amrawati, Wardha Chandrapur, Latur, Nashik, Dhuley, Beed and Aurangabad districts contribute more area and production to the state pool. In genetic improvement, selection of suitable parents is important for development of better hybrids. The per se performance of parental lines provides clues, however, reliable information on magnitude of heterosis, combining ability of parents for yield and its component characters and gene action involved in the inheritance in different characters are more helpful in selecting appropriate parents and desirable cross combinations for commercial exploitation of hybrid vigour.

In genetic improvement, selection of suitable parents is important for development of better hybrids. The per se performance of parental lines provides clues, however, reliable information on magnitude of heterosis, combining ability of parents for yield and its component characters and gene action involved in the inheritance in different characters are more helpful in selecting appropriate parents and desirable cross combinations for commercial exploitation of hybrid vigour. Different mating designs have been used by different workers as an aid in the choice of parents and to understand their genetic worth. Line $\mathrm{x}$ Tester analysis was suggested by Kempthorne (1957) to elucidate the nature of gene action and combing ability of parents for different characters. Line $\mathrm{x}$ Tester analysis is a useful technique for screening large numbers of lines for identifying the best combiners. Similarly knowledge about nature of gene action governing the expression of various traits helps in determining the strategies to be adopted. Combining ability studies helps in identification of better combing parents and the best specific cross combinations for their further utilization in any breeding programme. However, the cross combination as identified has to be tested on large scale before their exploitation at commercial level. Estimation of genetic parameters is needed to understand the genetic architecture of yield and yield contributing components. Information about type of gene action, heterosis and combing ability for all the yield contributing traits would be of immense help for a plant breeder to decide about the proper breeding procedure to be adopted and the characters on which the selection has to be made. Considering the importance of 
heterosis and combing ability studies in improvement of brinjal crop, the present investigation "Genetic analysis of $F_{1}$ hybrids in brinjal" was carried out.

\section{Materials and Methods}

The present investigation entitled "Genetic analysis of $F_{1}$ hybrids in brinjal" was undertaken during kharif and summer season of 2014-15 at Department of Horticulture, Dr. Panjabrao Deshmukh Krishi Vidyapeeth, Akola with the objective to estimate the heterosis for yield and its component traits and to estimate gca and sca effects for yield and its component traits. For this purpose, eleven geographical and genetically diverse parents of various economic traits (four lines and seven testers) were crossed in line $\mathrm{x}$ tester mating design to obtain $28 \mathrm{~F}_{1} \mathrm{~s}$. These crosses, parents and check were grown in kharif and summer season of 2014-15 in randomized block design with three replications. The data was recorded on five selected plants and was recorded for ten characters viz., number of fruits per branch, number of fruits per plant, fruit set, fruit length, fruit diameter, fruit weight, yield per plant, yield per plot, yield per hectare, number of seeds per fruit.

\section{Results and Discussion}

Among female parents, (Table 1) Bhatai Local and Wadsa Local exhibited significant high gca effects for yield and yield related traits. Bhatai Local showed significant and desirable gca effects for eight characters namely numbers of fruits per branch (0.36), number of fruits per plant (2.85), fruit set (3.12), yield per plant (0.08), yield per plot (1.53), yield per hectare (21.23), number of seeds per fruit (-26.51) and leaf chlorophyll content (-3.41).Similarly, Wadsa Local followed by Aruna exhibited significant and desirable gca effects for eight yield and yield contributing characters.
Among the male parents, (Table 1) DBSR-52 and Ruchira exhibited high gca effects for yield and yield related traits. DBSR-52 showed significant and desirable gca effects for characters like numbers of fruits per branch (0.78), number of fruits per plant (2.33), fruit set (2.10), length of fruit (0.83), weight of fruit (8.05), yield per plant $(0.33)$, yield per plot (6.51) yield per hectare (75.88) and number of seeds per seed (138.81).Similarly, Ruchira exhibited high gca effects in eleven and Chandur Local in eight characters. Based on estimates of general combining ability effects, parents DBSR-52, Ruchira, Bhatai Local, Wadsa Local, Chandur Local and Aruna could be identified as good general combiner showing sufficient promise and potential in combining breeding.

Based on estimates of general combining ability effects, (Table 1) parents DBSR-52, Ruchira, Bhatai Local, Wadsa Local, Chandur Local and Aruna could be identified as good general combiner showing sufficient promise and potential in cross breeding. Due to high general combining ability effects corresponding with additive gene action (Griffing, 1956) and represents the fixable genetic components of variation, these parents appear worthy of exploitation. Above findings are in conformity with the observations of Biradar et al., (2005) Bisht et al., (2006), Suneetha et al., (2008) and Chaudhari and Didel (2014). The Patil and Shinde (1989) and Sadawarte et al., (1993) reported highly significant gca effects for yield and its component, suggesting predominance of additive gene action. Padmanabhan and Jagdish (1996) found additive and non additive gene action in all characters under study and found Cluster White as a good combiner for early flowering and fruits per plant. Kumar et al., (1996) reported highest significant negative gca effects for days to $50 \%$ flowering in parent SM-6 as a good combiner. Bulgandi (2000) founds good 
combining ability in two lines and one tester out of eleven parents along with their significant positive effects. Genotype R-1 proved as best general combiner for days to $50 \%$ flowering and earliness, P-3 for plant height, C-2 for average fruit weight, fruit diameter, fruit size and yield per plant, whereas I-9 proved good geneal combiners for fruit length. Mishra et al., (2013) identified the lines Punjab Neelam, DBSR-31, Ramnagar Giant, BR-SPS-14, DBSR-2 and Pant Rituraj as most promising parents for inclusion in hybridization programme with the aim to improve fruit yield as well as other important yield and yield contributing characters.

Table.1 Estimates of general combing ability ( $\mathrm{gca}$ ) effects for different characters in brinjal (L x T)

\begin{tabular}{|c|c|c|c|c|c|c|c|c|c|c|}
\hline \multirow{2}{*}{$\begin{array}{l}\text { Sr. } \\
\text { No. }\end{array}$} & \multirow[t]{2}{*}{ Genotypes } & & & & & & & \multirow[b]{2}{*}{$\begin{array}{c}\text { Yield /plant } \\
(\mathrm{kg})\end{array}$} & \multirow[b]{2}{*}{ Yield (q/ha) } & \multirow[b]{2}{*}{$\begin{array}{l}\text { Number of } \\
\text { seeds / fruit }\end{array}$} \\
\hline & & $\begin{array}{c}\text { Number } \\
\text { of fruits / } \\
\text { branch }\end{array}$ & $\begin{array}{c}\text { Number } \\
\text { of fruits/ } \\
\text { plant }\end{array}$ & $\begin{array}{c}\text { Fruit set } \\
(\%)\end{array}$ & $\begin{array}{l}\text { Fruit length } \\
\text { (cm) }\end{array}$ & $\begin{array}{l}\text { Fruit dia. } \\
\qquad(\mathrm{cm})\end{array}$ & $\begin{array}{c}\text { Fruit } \\
\text { weight (g) }\end{array}$ & & & \\
\hline & \multicolumn{10}{|l|}{ Female } \\
\hline 1 & Aruna & $0.360 * *$ & $1.319 * *$ & 0.298 & $-1.283 * *$ & -0.123 & $-7.022 * *$ & $-0.082 * *$ & $-16.898 *$ & $-196.883 * *$ \\
\hline 2 & $\begin{array}{c}\text { Bhandara } \\
\text { local }\end{array}$ & $-0.418 * *$ & $-3.476 * *$ & $-1.462 * *$ & $-1.239 * *$ & $0.534 * *$ & 1.393 & $-0.195 * *$ & $-41.643 * *$ & $190.436 * *$ \\
\hline 3 & Wadsa local & $-0.309 * *$ & $-0.694 *$ & $-1.957 * *$ & $4.229 * *$ & $-0.375^{* *}$ & $10.729 * *$ & $0.193 * *$ & $37.302 * *$ & $32.960 *$ \\
\hline \multirow[t]{4}{*}{4} & Bhatai local & $0.368 * *$ & $2.851 * *$ & $3.121 * *$ & $-1.707 * *$ & -0.036 & $-5.101 * *$ & $0.085 * *$ & $21.239 * *$ & -26.512 \\
\hline & S.E.(gi) & 0.0611 & 0.3248 & 0.494 & 0.128 & 0.081 & 1.562 & 0.031 & 6.487 & 14.324 \\
\hline & S.E.(gi-gj) & 0.0864 & 0.4593 & 0.697 & 0.182 & 0.114 & 2.209 & 0.044 & 9.174 & 20.257 \\
\hline & \multicolumn{10}{|l|}{ Male } \\
\hline 1 & ManjariGota & $0.467 * *$ & $2.794 * *$ & $4.009 * *$ & $-0.688 * *$ & $-0.265 *$ & $-7.565 * *$ & 0.009 & 4.315 & $-81.931 * *$ \\
\hline 2 & $\begin{array}{l}\text { Chandur } \\
\text { Local }\end{array}$ & 0.122 & $2.232^{* * *}$ & $3.948 * *$ & -0.087 & 0.023 & -1.457 & $0.196 * *$ & $52.972 * *$ & 36.753 \\
\hline 3 & Ruchira & -0.028 & $3.558 * *$ & $2.254 * *$ & 0.205 & $0.725 * *$ & 2.502 & $0.422 * *$ & $93.944 * *$ & $-137.981 * *$ \\
\hline 4 & $\begin{array}{c}\text { Krishna } \\
\text { Kathi }\end{array}$ & $-1.219 * *$ & $-7.449 * *$ & $-8.154 * *$ & -0.294 & $0.567 * *$ & $14.523 * *$ & $-0.370 * *$ & $-79.793 * *$ & $213.883 * *$ \\
\hline 5 & White Round & $-0.566 * *$ & $-4.613 * *$ & $-4.636 * *$ & -0.013 & -0.049 & $-4.292 *$ & $-0.447 * *$ & $-103.872 * *$ & $113.228 * *$ \\
\hline 6 & DBSR-52 & $0.788 * *$ & $2.330 * *$ & $2.107 * *$ & $0.837 * *$ & $-0.393 * *$ & $8.052 * *$ & $0.330 * *$ & $75.882 * *$ & $-138.815 * *$ \\
\hline 7 & White Brinjal & $0.436 * *$ & $1.150 * *$ & 0.471 & 0.040 & $-0.608 * *$ & $-11.763 * *$ & $-0.141 * *$ & $-43.449 * *$ & -5.137 \\
\hline & S.E.(gi) & 0.081 & 0.429 & 0.653 & 0.17 & 0.107 & 2.066 & 0.041 & 8.582 & 18.949 \\
\hline & S.E.(gi-gj) & 0.114 & 0.607 & 0.923 & 0.241 & 0.152 & 2.923 & 0.058 & 12.136 & 26.798 \\
\hline
\end{tabular}

$*, * *=$ significant at $5 \%$ and $1 \%$ respectively. 
Table.2 Estimates of specific combing ability (sca) effects for different characters in brinjal ( $\mathrm{L} \mathrm{x} \mathrm{T)}$

\begin{tabular}{|c|c|c|c|c|c|c|c|c|c|c|}
\hline \multirow{2}{*}{$\begin{array}{l}\text { Sr. } \\
\text { No. }\end{array}$} & \multirow[t]{2}{*}{ Crosses } & \multirow[b]{2}{*}{$\begin{array}{l}\text { Number of } \\
\text { fruits per } \\
\text { branch }\end{array}$} & \multirow[b]{2}{*}{$\begin{array}{l}\text { Number of } \\
\text { fruits/plant }\end{array}$} & \multirow[b]{2}{*}{$\begin{array}{l}\text { Fruit set } \\
(\%)\end{array}$} & \multirow[b]{2}{*}{$\begin{array}{l}\text { Fruit } \\
\text { length } \\
(\mathrm{cm})\end{array}$} & \multirow[b]{2}{*}{$\begin{array}{l}\text { Fruit dia. } \\
\quad(\mathrm{cm})\end{array}$} & \multirow[b]{2}{*}{$\begin{array}{c}\text { Fruit } \\
\text { weight (g) }\end{array}$} & \multirow[b]{2}{*}{$\begin{array}{c}\text { Yield } \\
\text { /plant } \\
(\mathrm{kg})\end{array}$} & \multirow[b]{2}{*}{$\begin{array}{l}\text { Yield } \\
\text { (q/ha) }\end{array}$} & \multirow[b]{2}{*}{$\begin{array}{l}\text { Number of } \\
\text { seeds / fruit }\end{array}$} \\
\hline & & & & & & & & & & \\
\hline \multirow[t]{7}{*}{$\mathbf{1}$} & Aruna x ManjariGota & -0.244 & -0.733 & -0.321 & 0.220 & 0.038 & -0.845 & -0.032 & -9.088 & 44.550 \\
\hline & x Chanduri local & $0.310^{*}$ & $2.101 *$ & 0.659 & 0.001 & $0.332 *$ & -0.422 & $0.128^{*}$ & $38.244^{*}$ & 22.833 \\
\hline & x Ruchira & $0.370^{* *}$ & $1.710^{*}$ & $2.728 *$ & -0.628 & -0.259 & -3.096 & -0.070 & -19.272 & $79.200 *$ \\
\hline & x Krishna kathi & $-0.569 * *$ & $-2.197 *$ & $-3.561 * *$ & 0.456 & 0.118 & $6.773^{*}$ & 0.090 & 18.452 & -36.203 \\
\hline & x White Round & 0.027 & -0.056 & -1.100 & 0.400 & 0.091 & $6.740^{*}$ & 0.052 & 17.322 & -65.508 \\
\hline & x DBSR-52 & $0.777 * *$ & 1.656 & $2.610^{*}$ & -0.536 & $-0.511 *$ & -3.709 & 0.007 & 0.220 & $-84.566 *$ \\
\hline & x White Brinjal & -0.090 & -1.139 & -0.446 & 0.087 & 0.190 & -2.440 & $-0.176 *$ & -25.877 & 39.695 \\
\hline \multirow[t]{7}{*}{8} & $\begin{array}{l}\text { Bhandara local x } \\
\text { Manjari Gota }\end{array}$ & -0.098 & 0.713 & 1.017 & 0.358 & 0.340 & $7.272^{*}$ & $0.215 *$ & $46.103 * *$ & -60.169 \\
\hline & x Chanduri local & -0.045 & $-3.761 * *$ & -1.882 & -0.655 & -0.194 & -3.886 & $-0.186 *$ & -20.812 & -24.452 \\
\hline & x Ruchira & -0.123 & -1.398 & $-4.708 * *$ & $0.778^{*}$ & $0.575 * *$ & -2.336 & -0.051 & -14.996 & -63.152 \\
\hline & x Krishna kathi & $0.634 * *$ & $4.225 * *$ & $4.498 * *$ & 0.152 & -0.182 & $-8.461 *$ & 0.056 & 10.556 & 71.018 \\
\hline & x White Round & -0.142 & 0.044 & -0.921 & 0.254 & 0.088 & 6.334 & 0.099 & -0.263 & -31.894 \\
\hline & x DBSR-52 & -0.271 & 0.011 & $0.550^{*}$ & -0.190 & -0.303 & $6.696^{*}$ & -0.038 & -10.129 & 47.648 \\
\hline & x White Brinjal & 0.045 & 0.166 & 1.446 & -0.397 & -0.323 & 0.381 & -0.094 & -10.461 & 61.001 \\
\hline \multirow[t]{7}{*}{15} & $\begin{array}{l}\text { Wadsa local x } \\
\text { ManjariGota }\end{array}$ & -0.127 & $-1.713 *$ & -2.184 & $-0.775 *$ & -0.422 & $-8.432 *$ & $-0.292 * *$ & $-59.284 * *$ & 29.407 \\
\hline & x Chanduri local & -0.274 & -0.502 & -0.098 & $1.342 * *$ & $0.430 *$ & $11.034 * *$ & $0.183 *$ & $39.274 *$ & 29.057 \\
\hline & x Ruchira & $0.350^{*}$ & $1.680^{*}$ & $1.258^{*}$ & $0.625^{*}$ & -0.105 & $8.713^{*}$ & $0.175^{*}$ & $34.396^{*}$ & 38.757 \\
\hline & x Krishna kathi & 0.201 & 0.370 & -1.730 & $-1.207 * *$ & 0.039 & -1.540 & -0.120 & -21.065 & $76.360 *$ \\
\hline & x White Round & $0.346 *$ & 1.561 & $2.915 *$ & $-0.721 *$ & -0.112 & $-9.002 *$ & -0.142 & -18.913 & -70.551 \\
\hline & x DBSR-52 & $-0.341 *$ & $-1.744 *$ & -2.214 & $0.897 * *$ & $0.396^{*}$ & $7.578^{*}$ & -0.019 & 1.130 & -30.876 \\
\hline & x White Brinjal & 0.048 & 1.613 & 2.052 & -0.060 & -0.030 & -0.350 & $0.315 * *$ & $34.461 *$ & $-72.154^{*}$ \\
\hline \multirow[t]{10}{*}{22} & $\begin{array}{l}\text { Bhatai local x } \\
\text { Manjari Gota }\end{array}$ & $0.468 * *$ & $1.732 *$ & 1.488 & 0.197 & 0.045 & 2.005 & 0.110 & 22.269 & -13.788 \\
\hline & x Chanduri local & 0.298 & $2.163 *$ & $1.321 *$ & $-0.687 *$ & -0.373 & -6.726 & -0.124 & $-36.706 *$ & -27.438 \\
\hline & x Ruchira & -0.101 & 0.616 & $2.720^{*}$ & -0.374 & -0.210 & 1.720 & $0.146^{*}$ & $39.871 *$ & $-74.805^{*}$ \\
\hline & x Krishna kathi & -0.266 & $-2.398 * *$ & 0.793 & 0.599 & 0.025 & $7.228^{*}$ & -0.026 & -7.943 & $-111.175^{* *}$ \\
\hline & x White Round & -0.231 & -1.549 & -0.894 & 0.067 & -0.067 & -1.072 & -0.010 & 1.854 & $167.954 * *$ \\
\hline & x DBSR-52 & -0.165 & 0.076 & -0.378 & -0.172 & $0.417 *$ & -1.565 & 0.050 & 8.779 & 67.794 \\
\hline & x White Brinjal & -0.003 & -0.640 & $-3.052 *$ & 0.371 & 0.163 & 2.410 & -0.045 & 1.876 & -28.542 \\
\hline & S.E.(si) & 0.1617 & 0.8593 & 1.3054 & 0.3399 & 0.2139 & 4.133 & 0.0819 & 17.1631 & 37.8983 \\
\hline & S.E.(sij-skl) & 0.2287 & 1.2152 & 1.846 & 0.4807 & 0.3025 & 5.8449 & 0.1158 & 24.2722 & 53.5963 \\
\hline & S.E.(sij-sik) & 0.1933 & 1.027 & 1.5602 & 0.4063 & 0.2556 & 4.9399 & 0.0978 & 20.5138 & 45.2971 \\
\hline
\end{tabular}

$*, * *=$ significant at $5 \%$ and $1 \%$ respectively.

Among the twenty eight crosses (Table 2), four crosses exhibit significant sca effects for most of the characters. The $\mathrm{F}_{1}$ hybrid, Wadsa Local x Ruchira was found superior with high sca effects in eight characters viz., numbers of fruits per branch(0.14), number of fruits per plant (0.41), fruit set (1.25), length of fruit (0.52), weight of fruit (3.71), yield per plant (0.07), yield per plot (2.31), yield per hectare (24.39) followed by the cross Wadsa Local $x$
Chandur Local in seven characters viz.,, length of fruit (1.34), diameter of fruit (0.23), weight of fruit (11.03), yield per plant (0.18), yield per plot (1.66), yield per hectare (39.27), Aruna $\mathrm{x}$ Chandur Local in six characters viz., numbers of fruits per branch (0.021), number of fruits per plant (2.10), fruit diameter (0.33), yield per plant $(0.12)$, yield per plot $(0.26)$, yield per hectare (18.24) and Bhatai Local x Ruchira in five characters viz., fruit set (0.72), 
yield per plant (0.04), yield per plot (1.62), yield per hectare (9.87) and number of seeds per fruit (-54.80). Similar results for desirable sca effects were reported by Vinodkumar and Pathania (2003), Biswajit et al., (2004), Ashwani and Khandelwal (2005), Bendale et al., (2005), Premalakshme et al., (2005), Praneetha and Veeragavatham (2007), Shafeeq et al., (2007), Suneetha et al., (2008), Rai and Asati (2011) and Sane et al., (2011)

The general and specific combining ability variances for the traits studied indicated the gene action associated with them.

Broadly, general combining ability variance indicate additive gene action and additive $\mathrm{x}$ additive interaction effects, while specific combining ability effects correspond with non-additive gene action like dominance and other epistatis interactions viz., additive $\mathrm{x}$ dominance and dominance $\mathrm{x}$ dominance (Hayman, 1958).

The ratio between genetic variance of gca $(\sigma$ gca) and genetic variance of sca ( $\sigma$ sca) indicates the gene action. If the ratio is greater than one indicates the additive gene action and less than one indicates non additive gene action. As the additive variance was predominance for yield and also other characters which contribute for the yield, transgressive (recombinant) breeding is useful.

In conclusions, among the eleven parents, Bhatai Local, Aruna, Ruchira, Wadsa local and Chandur local have found better parents on the basis of high per se performance with high gca effects in most of the characters, whereas, among twenty eight crosses, Wadsa Local x Ruchira, Wadsa Local x Chandur Local, Bhatai Local x Ruchira and Aruna $\mathrm{x}$ Chandur local were found better promising on the basis of high per se performance with high sca effects in most of the characters.

\section{References}

Anonymous, 2017. Area and production of vegetable crops in India. Indian Horticulture Database, National Horticulture Board, Pub. 2017.

Ashwani, R. C. and R. C. Khandelwal, 2005.Combining ability studies in brinjal. Indian J. Horticulture, 62(1): 3740.

Bendale, V. W., S. V. Mane, S. G. Bhave, R. R. Madav and S. B. Desai, 2005. Combination ability studies on growth and developmental characters in brinjal. International J. of Agricultural Sciences, 1(1): 30-33.

Bhaduri, P. N. 1951. Inter-relationship of non-tuberiferous species of Solanumwith some consideration on the origin of brinjal ( $S$. melongena L.).The Indian Journal of Genetics and Plant Breeding, 11: 75-82.

Biradar, A. B., A. D. Dumbre and P. A. Navale, 2005.Combining ability studies in brinjal. J. of Maharashtra Agriculture Universities, 30(3): 342.

Bisht, G. S., M. C. Singh, S. K. Major Singh and M. Rai, 2006.Combining ability analysis in brinjal (Solanum melongena L.). Veg. Sci., 33(1): 68-70.

Biswajit, P., Y. V. Singh and H. H., Ram, 2004. Combining ability studies for yield and yield attributing traits in round fruited eggplant (Solanum melongenaL.) under Tarai condition of Uttaranchal, India. Capsicum and Eggplant Newsletter, 23:137-140.

Bulgundi, S. S., 2000. Heterosis and combining ability in brinjal (Solanum melongena L.). M. Sc. (Agri.) Thesis, Uni. Agric. Sci., Dharwad (India).

Choudhary, B. 1976. Evolution of Crop Plants, Ed. N.W. Simmonds, Longman Inc. London.

Choudhary, S. and Didel, R.P. 2014. Combining ability analysis for growth 
and yield components in brinjal (Solanum melongena L.) Asian J. Bio Sci. 9(1):88-92.

Griffing, 1956.Concept of general and specific combining ability in relation to diallel crossing system. Australian J. Sci., 9: 463-493.

Hayman, B.I., 1958.The separation of epistatic from additive and dominance variation in generation means. Heridity. 12: 371-390.

Kempthrone, O. 1957. An Introduction to Genetic Statistics, John Wiley and Sons, Inc., New York, pp. 208-223.

Kumar, R., D.N. Singh and K. K. Prasad, 1996. Combining ability analysis in brinjal (Solanum melongena L.). J. Research. 8(1): 45-49.

Mishra, R., A.K. Singh, V. ManjuVani, B.K. Singh, Harit Kumar and B.V. Rajkumar, 2013.Combining ability studies in elite breeding lines of brinjal (Solanum melongena L.) for plant characters. Asian J. of Bio and Life Sci. 2(3):275278.

Padmanabham, V. and C. A. Jagadish, 1996.Combining ability studies on yield potential of round fruited brinjal (Solanum melongena L.). Indian Journal ofGenetics, 56(2): 141-146.

Patil, H. S. and Y. M. Shinde, 1989.Combining ability in egg plant. Indian J. Genet. 49(2): 155-159.

Praneetha, S. and D. Veeraragavantham, 2007. Combining ability studies in brinjal (Solanum melongena L.) South Indian Hort. 53(1-6): 58-61.

Premalakshme, V., T. Thangaraj, D.
Veeraragavatham and T. Arumugam, 2005. Heterosis and combining ability in tomato (Solanum lycopersicum L.).Veg. Sci., 32 (1): 47-50.

Rai, N. and B. S. Asati, 2011.Combining ability and gene action studies for fruit yield and yield contributing traits in brinjal. Indian J. Hort. 68(2): 212-215.

Sadawarte, K.T., V.N. Dod, P.B. Kale, R.V. Wankhade and A.T. Joshi. 1993. Combining ability in brinjal. PKV Res. J. 17(1): 37- 43.

Sane, S. C., M. N. Bhalekar, B. T. Patil, S. S. Dhumal, A. N. Gaikwad and D. B. Kshirsagar, 2011. Combining ability for yield and yield contributing characters in brinjal (Solanum melongena L.). Asian J. Hort. 6(1): 215-217.

Shafeeq, A., K. Madhusudan, R.R. Hanchinal, A.G. Vijaykumar and P.M. Salimath, 2007. Heterosis in brinjal. Karna. J. of Agric.Sci. 20(1):33-40.

Suneetha, Y., K. B. Kathiria, P. K. Kathiria and T. Srinivas, 2000. Combining ability for yield and yield components in late summer brinjal. New Botanist. 1(4): 1-11.

Vavilov, N. I. 1931. The role of Central Asia in the origin of cultivated plants. Bulletin of Applied Botany - Genetics and Plant Breeding, 26(3): 3-44.

Vinodkumar and N. K. Pathania, 2003.Combining ability studies in brinjal (Solanum melongena L.). Veg. Sci., 30 (1): 50-53. (Solanum melongena L.). Veg. Sci., 26(1): 41-44.

\section{How to cite this article:}

Khobragade, R.I., P.K. Nagre and Nandeshwar, V.N. 2019. Combining Ability Studies on Brinjal for Yield and Yield Components Traits. Int.J.Curr.Microbiol.App.Sci. 8(08): 16971703. doi: https://doi.org/10.20546/ijcmas.2019.808.200 